\title{
MEALS ON WHEELS: RESTAURANT AND HOME MEAL PRODUCTION AND THE EXEMPTION OF FOOD FROM SALES AND VALUE ADDED TAXES
}

\author{
Aled Ab Iorwerth \\ John Whalley \\ Working Paper 6653 \\ http:/www.nber.org/papers/w6653
}
NATIONAL BUREAU OF ECONOMIC RESEARCH 1050 Massachusetts Avenue
Cambridge, MA 02138
July 1998

We are grateful to SSHRC for research support, and to Ig Horstman and participants at a seminar in Western Ontario for helpful comments. Any opinions expressed are those of the author and not those of the National Bureau of Economic Research.

(C) 1998 by Aled Ab Iorwerth and John Whalley. All rights reserved. Short sections of text, not to exceed two paragraphs, may be quoted without explicit permission provided that full credit, including (C notice, is given to the source. 
Meals on Wheels: Restaurant and Home Meal

Production and the Exemption of Food from

Sales and Value Added Taxes

Aled $\mathrm{Ab}$ Iorwerth and John Whalley

NBER Working Paper No. 6653

July 1998

ABSTRACT

This paper discusses efficiency considerations underlying the widespread exemption of food from sales and value added taxes, in contrast to the distributional considerations usually used to justify them, analyzing the implications for tax policy. Although there are increasing returns in both household and market production of meals there are, nonetheless, critical differences between them. Market production is imperfectly competitive leading to average cost pricing with free entry, but because production in the household involves only one firm, any household can appropriate the consumer surplus from its own production and hence marginal cost price. We use a numerical simulation model using 1994 Canadian data with increasing returns to scale in both home and restaurant meals resulting from fixed costs and where a Dixit-Stiglitz Chamberlinian structure is used to represent restaurant meal provision. Because food (along with time and durables) is an input into home provided meals, more than full taxation of food would seem to be justified to offset the non taxation of time inputs into household production, even under constant returns to scale. Because of the differences in pricing rules between market and household production with increasing returns, not only are gains from taxing food higher but they are amplified by also subsidizing food in restaurant use, and even more by subsidizing all marginal cost components of restaurant meal provision (including labour). On efficiency grounds, the exemption of food in sales and value added taxes emerges from our analyses as poor and misguided policy, and especially so in the increasing returns case.

Aled Ab Iorwerth

Department of Economics

Social Science Centre, Room 4071

University of Western Ontario

London, Ontario N6A 5C2

Canada
John Whalley

Department of Economics

Social Science Centre, Room 4071

University of Western Ontario

London, Ontario N6A 5C2

Canada

and NBER

whalley@sscl.uwo.ca 


\section{INTRODUCTION}

Analyses of the impacts of taxes have traditionally taken place largely in a perfectlycompetitive market setting. Atkinson and Stiglitz (1980) were among the first to examine the consequences of imperfectly competitive structures for the effects of taxes, with this work further developed in Katz and Rosen (1985), Stern (1987), Dierickx et al. (1988), Myles (1989), Konishi (1990), Konishi et al. (1990), Delipalla and Keen (1992), Cremer and Thisse (1994) and Myles (1995a). ${ }^{2}$ Our point of departure is that these analyses have only examined the implications of imperfect competition for market production, not the implications for taxes of scale economies in both household and market production. Here we examine a case where a product (meals) may be produced in both the market (restaurant meals) and in the household (home meals), and analyze the implications of exempting food from sales or value added taxes.

We use models with scale economies at market and household level. The production of meals requires investments in cookers, microwaves, refrigerators, and other equipment regardless of whether produced in a restaurant or in the household. Scale economies and product differentiation in the market yield conventional Chamberlinian monopolistic competition, and restaurants in the market sector will price at average cost under free entry. In contrast, only the household undertakes household production and there are no issues of entry or exit. Since households can perfectly price discriminate they can capture all of the consumer surplus generated from household production and need only ensure that the surplus generated from production is greater than the fixed cost of production. They can then efficiency price by equating the marginal cost of production to its marginal benefit.

${ }^{2}$ For a review of this literature, see Myles (1995b) 
We use the above structure to examine the treatment of food by the tax system. The current practice in the retail sales and value added taxes of most US states and a number of countries, including Canada and the UK, is to exempt food since food is seen as more heavily purchased by the poor. Despite this, excluding it from tax may be judged to be poorly targeted redistribution since the rich as well as the poor buy food and benefit from the tax break. ${ }^{3}$

There is little prior literature discussion of efficiency considerations of the food exemption, beyond the obvious optimal tax implications which suggest either Ramsey taxes or heavier taxes on complements of leisure (see Atkinson and Stiglitz (1980)). Wilson's (1989) discussion of the optimal product coverage of sales taxes is one exception, but is not directly related to tax exemptions based on product characteristics as we discuss here. Newberry (1986) discusses the need for input taxes when taxation of final goods is not possible. Although the effects of taxes when both household and market production is possible have been discussed by Sandmo (1990) and Boskin (1975), the incorporation of scale economies at both household and market level has not been previously considered, and has important implications for tax policy design.

We model food along with time as inputs into household meal production, pointing out that since time is not taxed, exempting food from a retail sales tax or a VAT removes a factor input distortion but worsens the distortion between market (restaurant) and household meal consumption. Even in the constant returns case, more than full taxation of food can be merited on efficiency grounds to partially offset the tax free treatment of labour inputs into household production. Thus, both inter commodity (home and restaurant production of meals) and household production input

${ }^{3}$ See Davies (1986) for a discussion of the distributional implications of the food exemption. 
distortions (between food and time) need to be considered in evaluating the appropriate tax treatment of food under a sales tax or VAT.

We first build a simple constant returns numerical simulation model with both household and restaurant meal production as part of a wider model of the economy incorporating non taxed market provided inputs into household production. We use data for 1992 from the Canadian time use survey, input-output tables and consumer expenditure surveys, and conclude that in the constant returns to scale case (depending upon the choice of elasticities) more than full taxation of food under a retail sales tax or a VAT seems called for on efficiency grounds to offset the non taxation of labour inputs in household production.

We then move on to analyze the increasing returns to scale case, arguing that not only is the case for taxing food stronger than with constant returns to scale, but that further supplementary tax or subsidy interventions may also be appropriate. In our formulation, there are fixed costs in both market (restaurant) and household production via the purchase of durable goods. Following Dixit and Stiglitz (1977), with free entry and product differentiation in the market portion of the economy, prices cover both fixed and variable costs and reflect average rather than marginal costs. For the household portion of production, households compare their surplus from consumption (consumer surplus) to the fixed costs involved in initiating production, but marginal cost price incremental production. This differential use of marginal and average cost pricing rules in household and market production adds a further distortion compared to constant returns to scale models which can also be partially offset through more than full taxation of food used in home meal production. Indeed, under this formulation, it is desirable to not only tax food in household use, but to subsidize food used by restaurants and to even subsidize all variable inputs to restaurant meals, including time. 
In further variants of our simulation structure which incorporates fixed costs and scale economies in production for both home and restaurant meals, differential pricing rules for home and restaurant meals is incorporated. The intuition that tax rates on currently exempt food products should be raised is supported by model results. Moreover, subsidizing food used by restaurants while taxing food used at home yields even larger welfare gains, as does subsidizing all variable inputs into restaurant production, including time.

In summary, we argue that the differing implications of scale economies for behaviour in the household and in the market have not been previously examined and that the incorporation of these has important implications for tax design, offering the issue of food exemption in a sales or value added tax as an example. Our results point towards food being more than heavily taxed under a VAT or retail sales tax, rather than exempted as at present. And in the increasing returns to scale case, even subsidizing food used by restaurants may be sensible policy, opposite to current government policy where restaurants face higher prices for their food inputs than the population at large. If current belief seems to be that the food exemption provides poorly targeted redistribution; our analysis indicates that it is even poorer policy on efficiency grounds. 


\section{THE FOOD EXEMPTION IN THE CONSTANT RETURNS CASE}

We first consider the more traditional constant returns case to illustrate the impact of the food exemption, prior to taking scale economies into account. We consider an economy with three product categories. The first are exclusively market provided goods, $M$, which can only be produced in the market portion of the economy, and include manufactured products, such as cars and electronics. The second are goods, $B$, where both market and household production are possible. Examples are restaurant meals and home cooking, daycare or self provided child care. The third are products, $I$, which, along with time, are inputs into both household and market production, such as food. These items, which in reality depend upon the country being analyzed, we will take to be tax exempt under the retail sales tax or VAT.

Given our focus on efficiency considerations in evaluating the exemption of food under the sales tax or VAT, we consider a representative consumer with a utility function

$$
U\left(M, B\left(B^{M}, B^{H}\right)\right)
$$

where $M$ and $B^{M}$ refer to goods produced in the market and $B^{H}$ to those produced in the household. These are produced using time, $T$, and market supplied inputs, $I$, (food). The goods $B^{M}$ and $B^{H}$ (market provided restaurant meals and household provided meals) are treated as qualitatively different, and are aggregated in preferences using the aggregator $B\left(B^{M}, B^{H}\right)$.

Technology is represented as

$$
\begin{aligned}
& F(T, I)=0 \\
& M=M\left(T^{M}\right) \\
& B^{M}=B^{M}\left(T^{B^{M}}, I^{B^{M}}\right) \\
& B^{H}=B^{H}\left(T^{B^{H}}, I^{B^{H}}\right)
\end{aligned}
$$


where (2) represents a transformation frontier defined over $T$ and $I^{4},(3)$ is the production function for $M$, (4) and (5) are production functions for $B^{M}$ and $B^{H}$ using as inputs time and produced inputs from (2). We assume a closed economy model in which consumption and production of $M, B^{M}, B^{H}$ are equal at the equilibrium prices. The model is completed by market clearing conditions in $I$,

$$
I=I^{B^{M}}+I^{B^{H}}
$$

and a time constraint

$$
T=T^{B^{M}}+T^{B^{H}}+T^{M}
$$

In this simple model, a comprehensive VAT (or retail sales tax) will tax $M, B^{M}$, and $I^{B^{H}}$; while a VAT (or retail sales tax) with product exemptions will only tax $M$ and $B^{M}$. A tax exemption for $I^{B^{H}}$ (food in home use) will weaken the tax distortion between time and inputs in household production of $B$ goods; but will intensify the tax distortion between consumption of $B^{M}$ and $B^{H}$. With a low substitution elasticity between time and other inputs, $I^{B^{H}}$, but high substitutability between market and household supply, product exemptions will be less preferred on efficiency grounds than full taxation of inputs under the VAT or retail sales tax; and indeed, typically more than full taxation of such inputs will be optimal.

Simple numerical general equilibrium computational techniques can be used to show the impacts of possible tax options in this model. Using CES production and demand structures, and adopting base case tax rates for a central case model specification, we can use a preference structure which nests home and restaurant meals into a composite of meals; and meals and other goods into

${ }^{4}$ This involves the simplifying assumption that the economy has a fixed resource availability which can yield alternative combinations of food and time (inputs into meal production). This is employed as a simplification to avoid cases where fixed factors (say, time) bear the burden of input taxes and yield little distortionary impact. It yields upward sloping supply functions for these inputs, and as such is an analytical convenience. 
consumption; and consumption and leisure into utility. This model can be calibrated to a base case equilibrium and counterfactual equilibrium analyses performed under alternative tax regimes. This allows the welfare impacts of alternative tax policies to be assessed using a money metric welfare measure, such as a Hicksian Equivalent or Compensating Variation of the change relative to the base case. In using the model in this way we ignore non labour value added in the economy (all capital use), all intermediate transactions (electricity in restaurants), and all foreign trade. While perhaps extreme, given the uncertainties over key elasticity parameters in such modelling efforts, these assumptions nonetheless allow us to explore indicative numerical simulation with broad policy implications in a simple and transparent manner.

Table 1 sets out details of and sources for a base case equilibrium data set for Canada for 1992 to which we have calibrated the above model, with slight further elaborations to include a household labour/leisure choice. This data set has been constructed using a variety of data sources. It uses time use survey data for households, market information on cost components for restaurants, and national accounts aggregates, and has been adjusted for consistency with the equilibrium solution concept in the model above. We then perform alternative counterfactual model calculations as sensitivity analysis for different specification of tax regimes using the model, and also under alternative elasticity configurations. 
$\underline{\text { Table } 1}$

Base Case 1992 Data Set For Canada To Which The Constant Returns to Scale Model Is Calibrated ${ }^{1}$

\begin{tabular}{|c|c|c|}
\hline \multicolumn{3}{|c|}{ 1. Production and Consumption Side of Economy } \\
\hline Restaurant Meals - & Value of Production and Consumption & $\$ 14.75$ bill \\
\hline & Value of Food Input & $\$ 4.84$ bill \\
\hline & Value of Time Input & $\$ 9.91$ bill \\
\hline Home Meals - & Value of Production and Consumption & $\$ 124.89$ bill \\
\hline & Value of Food Input & $\$ 39.28$ bill \\
\hline & Value of Time Input & $\$ 85.61$ bill \\
\hline Value of Leisure $\mathrm{Co}$ & ed - & $\$ 624.77$ bill \\
\hline Value of Other Mar & ood Produced and Consumed - & $\$ 335.88$ bill \\
\hline \multicolumn{3}{|c|}{ 2. Elasticity Configuration } \\
\hline Elasticity of Transfo & on Between $T$ and Food & 5.0 \\
\hline Elasticity of Substit & between Food and Time in Restaurants & 0.3 \\
\hline $\begin{array}{r}\text { Elasticity of Substit } \\
\text { Production }\end{array}$ & $\begin{array}{l}\text { between Food and Time in Household } \\
\text { eals }\end{array}$ & 0.3 \\
\hline $\begin{array}{r}\text { Elasticity of Substit } \\
\text { Meals in C }\end{array}$ & $\begin{array}{l}\text { between Restaurant Meals and Home } \\
\text { nption }\end{array}$ & 1.5 \\
\hline Elasticity of Substit & between Leisure and Consumption & 0.2 \\
\hline Elasticity between $\mathrm{N}$ & and Other Goods & 0.6 \\
\hline \multicolumn{3}{|l|}{ 3. Tax Rates } \\
\hline Sales Tax Rate on $N$ & & $15 \%$ \\
\hline Sales Tax on Food $u$ & A Home Produced Meals & $0 \%$ \\
\hline Income Tax Rate & & $0 \%$ \\
\hline
\end{tabular}

${ }^{1}$ See over for sources and adjustments. 


\section{Notes to Table 1} elasticities.

The data presented in Table 1 draw on a variety of Canadian data publications, and literature estimates for

\section{$\underline{\text { Production and Consumption Data }}$}

\section{Restaurant Meals:}

Production data from Market Research Handbook, Statistics Canada, Government of Canada, (Table 5-14) gives food purchased from restaurants (per capita/per week; projected to annual economy wide basis).

Value of Time Input: Input-Output Tables for 1992 show the ratio of food expenditures to wage and salary payments as 0.49 in the food services and accommodation sector (Input-Output Structure of the Canadian Economy, Statistics Canada, 1996).

Food Input: This is calculated by residual from production and time inputs.

Home Meals:

Production data generated by sum of time and food input costs.

Value of Time Input. We use Canadian time use survey data (Frederick (1995), Statistics Canada) on time spent per household on paid work and cooking (we ignore shopping time). We then take the ratio of cooking time to paid time and use wages and salaries data (Table 1, National Income and Expenditure Accounts, Statistics Canada) to generate the value of time input into cooking.

Value of Food Input: The Market Research Handbook for Canada reports weekly purchases of food per household. We project this estimate to an annual economy wide total. Bloskie (1995) estimates that $15.3 \%$ of personal expenditures are made on meals with $4.3 \%$ of the total made on restaurants and $11.0 \%$ made on food. Our base case data are consistent with this.

\section{Leisure Consumption:}

Canadian Time Use Survey Data for 1992 gives the ratio of free time (excludes sleep, education, and meal consumption) to paid work. Using National Accounts data on wages and salaries we construct an estimate of leisure consumption.

\section{Other Produced Market Goods:}

This is 1992 wages, salaries, and supplementary labour income from the National Accounts, less food and restaurant purchases.

\section{Elasticity Configuration:}

\section{Transformation Elasticity Between T and F:}

There are no literature estimates to our knowledge of this elasticity. A high elasticity implies a high supply elasticity for food, and we use 5.0 to ensure that the majority of any tax on food is passed forward to users (restaurants, home meal producers) rather than backwards to consumers. 
Elasticities Between Food and Time Inputs in Household and Market Production:

We adopt the strong assumption of identical technology between home and restaurant meal preparation, using a low value of 0.3 to reflect the difficulty of substituting between food and time, relative to between home and restaurant meals.

Elasticity Between Home and Restaurant Meals in Consumption:

We use data from the Canadian Restaurant Association showing a 7\% reduction in the share of Canadian household food expenditures on restaurant and home meals in response to the 7\% GST introduced in 1990 (cited by Piggott and Whalley (1998)).

Elasticities of Substitution Between Composite Meals, Other Goods, and Between Leisure and Consumption:

These are based on literature on demand side and labour supply estimation. 
Table 2 sets out results for changes from the present tax exempt treatment of food in Canada using the constant returns to scale model formulation above and the data in Table 1. Under an equal yield sales tax, which includes food for home use in the tax base, a small welfare gain results. There is a $5 \frac{1}{2} \%$ increase in restaurant meal consumption and $3 \%$ decrease in home meal provision (the initial base value for consumption of restaurant meals is lower). Both food prices and restaurant prices fall and time allocated to home meal production falls. The equal yield tax rate (which also applies to food) is $13.3 \%$ as against $15 \%$ in the non food taxation base case.

Results in Table 2 also indicate that optimal tax treatment in this case is to more than fully tax food for home use (at 23.0\%). This is because time in home meal preparation is free of tax, and a higher tax rate on food partially compensates for this. These results also indicate the key role that other preexisting taxes play in such an analysis. With a preexisting $30 \%$ income tax the welfare gain increases by several orders of magnitude. This is because the tax exemption of food becomes a marginal distortion, operating alongside the income tax free treatment of time in home use.

Table 3 reports results using elasticity variations around the central case used above. Reducing the elasticity between food and time in household production increases the welfare gain from taxing food (the taxed input is more difficult to substitute out of). Changing other elasticities have little effect. Gains remain positive across these cases but the effects are small. Clear literature guidance for some of the key elasticities is limited (our central case elasticities are set out in Table 1 with sources and justifications), but the uniform positive effects seem to point to taxing food, and the more so once the income tax enters the picture even though the aggregate gain seems not of great consequence. 
Table 2

Model Analysis of Alternative Tax Treatments of Food in the Constant Returns to Scale Case

\begin{tabular}{|l|c|}
\hline A. An Equal Yield Sales Tax Including Food For Home Use & \\
\hline Welfare gain (Hicksian EV in 1992 \$bill) & 0.15 \\
\hline \% Increase in Restaurant Meals & $5.59 \%$ \\
\hline \% Decrease in Home Meals & $2.86 \%$ \\
\hline \% Change in Gross Price of Food & $-0.8 \%$ \\
\hline$\%$ Change in Net Price of Restaurants & $-1.8 \%$ \\
\hline$\%$ Change in Time Allocated to Home Meal Production & $-1.76 \%$ \\
\hline $\begin{array}{c}\text { Equal Yield Tax Rate on Food (Base Case Tax Rate of 15\% on Non } \\
\text { Food Items) }\end{array}$ & $13.3 \%$ \\
\hline B. Implications of Alternative Tax Specifications & 0.18 \\
\hline $\begin{array}{c}\text { Welfare Gain (As \% of Base Case Meal Consumption) From Using } \\
\text { Optimal Tax Rate of 23\% on Food For Home Use }\end{array}$ & 0.85 \\
\hline $\begin{array}{c}\text { Welfare Gain (As \% of Base Case Meal Consumption) Under Full } \\
\text { Taxation of Food When a 30\%Income Tax is Present in } \\
\text { both Base and Counterfactual Cases }\end{array}$ & \\
\hline
\end{tabular}

$\underline{\text { Table } 3}$

Elasticity Sensitivity Analyses of Central Case Analyses in Table 2

\begin{tabular}{|c|c|}
\hline Elasticity Variations on Base Case & Welfare Gains (Hicksian EV) \\
\hline $\begin{array}{l}\text { (i) Reduce elasticity between Food } \\
\text { and Time in household production by } 1 / 22\end{array}$ & 0.16 \\
\hline $\begin{array}{l}\text { (ii) Half elasticities in preferences between } \\
\text { home and restaurant meals }\end{array}$ & 0.12 \\
\hline (iii) Double elasticities between leisure/consumption & 0.15 \\
\hline $\begin{array}{l}\text { (iv) Halve elasticities of transformation } \\
\text { between Time and Food }\end{array}$ & 0.16 \\
\hline
\end{tabular}




\section{THE FOOD EXEMPTION WITH INCREASING RETURNS TO SCALE}

We next consider the impact of the food exemption in sales or value added taxes where there are increasing returns to scale in both market and household production of meals. Scale economies and fixed costs in household production have been little studied in the literature, even though investment in, say, housing is a clear fixed cost for many household production activities, just as the purchase of durable goods (ovens, pans) is for home meal preparation.

We do this by following existing literature (Dixit-Stiglitz (1977)) on market based Chamberlinian formulations of market equilibria in the presence of scale economies due to fixed costs, to which we add a household production component. In the market portion of our model, each firm (restaurant) produces qualitatively different products subject to both fixed and variable costs. With free entry, zero profit conditions ensure that mark ups are endogenously determined to cover fixed costs, and the number of firms (varieties) is endogenously determined.

In the household sector, in contrast, there is only one firm per household. Households do not have to charge a mark up to themselves to cover fixed costs, because they can compare their net surplus over the cost of installing capacity (fixed costs, or the cost of durable goods), and marginal cost price any incremental production. There is also no adjustment in the number of producers as the size of household production varies. Thus, where there are fixed costs and increasing returns to scale in both market and household production, market based activity involves average cost pricing and free entry, while incremental household production will be priced at marginal cost.

Incorporating the food exemption into models with fixed costs at both household and market production level thus implies deciding on the design of tax policy in the presence of a different pricing structure across the two levels. This can compound both the welfare and output effects compared 
to the constant returns to scale case of either the food exemption or the introduction of taxes applied to food in household use.

Thus, following Dixit and Stiglitz (1977), we formulate the market component of the model as involving the maximization of a household utility function

$$
U(M, B)
$$

where, in the CES case,

$$
B=\left(\delta \cdot B_{H}^{\frac{(\sigma-1)}{\sigma}}+(1-\delta) \cdot B_{M}^{\frac{(\sigma-1)}{\sigma}}\right)^{\frac{\sigma}{\sigma-1}}
$$

and where $M, B, B_{H}, B_{M}$, are as before; and $\sigma$ is the substitution elasticity in CES preferences between household and market meals, $B_{H}$ and $B_{M}$. Since we assume all households have identical homothetic preferences, (8) can be taken as the representative household utility function.

The composite of meals (across restaurants (or varieties)), $B_{M}$ is given by

$$
B_{M}=\left(\sum_{i=1}^{N} B_{i, m}^{\rho}\right)^{\frac{1}{\rho}} \quad 0<\rho<1
$$

where $B_{i, m}$ is the market based production of restaurant $i$, and $\rho$ is the substitution elasticity between varieties in defining a composite of meals. $N$ is the number of restaurants, endogenously determined through free entry and the zero profit conditions. The restriction $0<\rho<1$ is imposed (following Dixit and Stiglitz) so that $B_{M}$ is still defined if an individual $B_{i, m}$ goes to zero, and the function (9) remains concave. Equation (8) allows a composite price index across varieties to be constructed as

$$
P_{B_{M}}=\left(\sum_{i=1}^{n}\left(P_{i, M}\right)^{\frac{\rho}{\rho-1}}\right)^{\frac{\rho-1}{\rho}} .
$$

where $P_{i, m}$ is the price of a meal at restaurant $i$ and $P_{B_{M}}$ is the price of a composite restaurant meal. If all firms are symmetric, the composite quantity and price indices are given by

$$
B_{M}=N^{\frac{1}{\rho}} \cdot B_{i, m}
$$

and 


$$
P_{B_{M}}=N^{\frac{\rho-1}{\rho}} \cdot P_{i, m} .
$$

We note that with $0<\rho<1$, (12) also implies that, given prices for individual varieties, any increase in the number of restaurants will lower the price of the composite good (even after allowing for the increase in $N$ ). This is because of the high weighting implicitly placed on variety in DixitStiglitz preferences. Thus, faced with an increase of one extra pizza added to a composite bundle of pizzas, consumers value the extra variety yielded by the extra pizza more highly than the extra volume, to the point that it is cheaper to provide one unit of composite utility with the extra variety.

The cost structure of each restaurant, reflecting increasing returns to scale, is given by

$$
C_{i, m}=F_{i}+c \cdot B_{i, m}
$$

where $F_{i}$ are fixed costs for restaurant $i, c$ are marginal food and wage costs per meal, and $C_{i, m}$ are the total costs for restaurant $i$ in meal production.

Using the same assumption as in Dixit and Stiglitz, namely that $N$ is large enough that the effect of changes in each restaurant price $P_{i, m}$ on the composite price $P_{B_{M}}$ is close to zero, with zero profit conditions and free entry in long run equilibrium, it follows that $P_{i, m}=c / \rho$.

From this, it also follows that

$$
B_{i, m}=\frac{F_{i}}{P_{i}-c}=\frac{\rho}{(1-\rho)} \cdot \frac{F_{i}}{c}
$$

and hence that

$$
\rho=\frac{c \cdot B_{i, m}}{F_{i}+c \cdot B_{i, m}}
$$

Using (9) and (12) and the household budget constraint on the demand side of the model, after some manipulation, yields

$$
n=\left(\frac{P_{B_{H}}}{P_{B_{M}}}\right)^{\sigma \rho}\left(\frac{1-\delta_{m}}{\delta_{m}}\right)^{\sigma \rho}\left(\frac{B_{H}}{B_{i, m}}\right)^{\rho}
$$


giving the equilibrium number of restaurants (varieties). Here $P_{B_{H}}$ and $B_{H}$ are the price and consumption of household production (priced at marginal cost). The household production component of the model reflects marginal cost pricing, similar to the constant returns to scale case, with the added restriction that the welfare surplus (in money metric terms) above marginal cost must exceed the fixed costs in order for household production to occur. In equilibrium, we simply need to check that this is the case.

We have used this structure with increasing returns to scale and variety in restaurant and home meal production to further examine the impact of the food exemption under a value added or sales taxes. We then apply this structure to again analyze the food exemption in a VAT or Sales Tax using the same 1992 Canadian data as earlier, but now incorporating scale economies at both household and market levels.

To implement this model variant we use the same calibration and counterfactual equilibrium approach as earlier, but now need additional information beyond that which was used earlier in the constant returns to scale case. We use the same base case data but supplement it by specifying the base case number of restaurants and a value of $\rho$ as set out in Table 4 .

\section{Table 4}

Additional Model Parameters Used in the Increasing Returns Case

\begin{tabular}{|l|l|}
\hline (i) $\rho$, elasticity of substitution across varieties & 0.5 \\
\hline (ii) $N$, no. of varieties in the base case & 100 \\
\hline
\end{tabular}

We also assume that non labour, non intermediate costs (effectively capital costs) determine fixed costs, and wages and salaries plus food input costs are variable costs. We use data on the ratio of fixed to variable costs in each symmetric restaurant as part of our increasing returns base case 
calibration. The elasticity parameter across varieties, $\rho$, is determined once the ratio of fixed to variable costs is set for each restaurant, (from (16)). We calibrate to an exogenously specified number of firms in our base 1992 data, which we take somewhat arbitrarily to be 100 .

Table 5 reports the central case results from this analysis. Comparing comparable increasing returns (fixed costs) and constant returns to scale cases in Table 5 indicate, as in the constant returns cases above, gains from removing the food exemption in the VAT (or sales tax), and an optimal tax rate on food inputs which is significantly higher than in the constant returns to scale case. In these cases, the presence of fixed costs produces a higher optimal tax rate on potentially exempt inputs, in part, because of the preexisting differential pricing of incremental production between the household and market sectors.

The welfare gains from taxing food used in household production are, however, over five times larger than in the constant returns to scale case. Restaurant meal volumes increase by $19 \%$, while home consumption of meals and time allocated to household meal preparation fall by smaller amounts, reflecting their higher base. The number of restaurants increase by $9 \%$, and the price of restaurant meals falls by $10 \%$. As we note above, the fall in restaurant meal prices reflects the higher weighting on variety over quantity in Dixit-Stiglitz type preferences, implying that with the added variety of restaurant meals generated by taxing food, the cost of providing one unit of utility from the composite restaurant bundle falls sharply. The equal yield tax rate in this case is $13 \%$, the same as in the constant returns to scale case. The welfare impact is once again raised considerably by incorporating an income tax into both base and counterfactual cases.

Table 6 reports results from cases where a wider variety of tax and subsidy interventions are used. Halving the tax on restaurant meals when taxing food used in household production more than 
doubles welfare gains. Taxing food used in household production and subsidizing the marginal costs of restaurants yields a further gain. Intervening in both of these ways when taxing home use of food yields an even larger gain. And an income tax set at $30 \%$ in both base and counterfactual cases yields further gains.

\section{$\underline{\text { Table } 5}$}

Central Case Analyses of the Implications of Taxing Food as an Input to Household Production in the Increasing Returns/Variety Case

\begin{tabular}{|c|c|c|}
\hline A. & $\begin{array}{l}\text { Extending the sales tax to cover food for household use on } \\
\text { an equal yield basis in the increasing returns case }\end{array}$ & \\
\hline & $\begin{array}{l}\text { - Welfare impact in terms of Hicksian EV in } 1994 \$ \\
\text { Bill }\end{array}$ & 0.82 \\
\hline & Equal yield tax rate on food for home use & $13.3 \%$ \\
\hline & Change in volume of restaurant meals & $+18.57 \%$ \\
\hline & Change in home consumption of meals & $-3.74 \%$ \\
\hline & $\begin{array}{l}\text { Change in time allocated to household meal } \\
\text { preparation }\end{array}$ & $-2.7 \%$ \\
\hline & Change in number of restaurants & $+8.7 \%$ \\
\hline & Change in net price of restaurant meals & $-10 \%$ \\
\hline B. & $\begin{array}{l}\text { Extending the sales tax to cover food for household use on } \\
\text { an equal yield basis in the constant returns to scale case }\end{array}$ & \\
\hline & $\begin{array}{l}\text { Welfare Impact in Constant Returns to Scale Case } \\
\text { in Terms of Hicksian EV in } 1994 \$ \text { Bill }\end{array}$ & 0.15 \\
\hline & Equal Yield Tax Rate on food for home use & $13.3 \%$ \\
\hline $\boldsymbol{F}$. & $\begin{array}{l}\text { Welfare impact in the increasing returns case under full } \\
\text { taxation of food when a } 30 \% \text { income tax is present in both } \\
\text { base and counterfactual cases. }\end{array}$ & 2.63 \\
\hline
\end{tabular}


Table 7 reports the impact of elasticity variations within the model, showing considerable sensitivity to some of the model parameter values. Halving the elasticity of substitution in preferences between home and restaurant meals reduces welfare gains by a factor of four, while halving the elasticity of substitution between food and time in household production reduces welfare gains has little effect. Finally increasing the ratio of variable to total costs in market production by half (reducing the relative size of the fixed cost component) halves the welfare gain.

While there is clearly sensitivity of these results to particular parameter values, the implication nonetheless remains that gains from taxing food for household use in the increasing returns case substantially exceed those from the constant returns case. Moreover, using other instruments while taxing food, such as subsidizing restaurant meals, has a rationale on efficiency grounds. 
$\underline{\text { Table } 6}$

\section{Comparing Across Policy Instruments When Taxing Food (Welfare Effects in Terms of Hicksian EV in Bill\$ 1992)}

\begin{tabular}{|ll|c|}
\hline A. & $\begin{array}{l}\text { Extending the sales tax to cover food on an equal yield } \\
\text { basis for household use (Base Case, Table 5) }\end{array}$ & 0.82 \\
\hline B. & $\begin{array}{l}\text { Extending both the sales tax on food for household use and } \\
\text { halve tax on to restaurant meals }\end{array}$ & 1.78 \\
\hline C. $\quad \begin{array}{l}\text { Extending the sales tax on food and instituting a subsidy to } \\
\text { marginal cost for restaurant meals by 10\% }\end{array}$ & 1.72 \\
\hline C. $\quad$ Combining B and C & 2.74 \\
\hline E. $\quad \begin{array}{l}\text { The same analysis as in case A, but with an income tax of } \\
30 \% \text { in both the base and counterfactual cases. }\end{array}$ & 2.63 \\
\hline
\end{tabular}

$\underline{\text { Table } 7}$

\section{Elasticity and Parametric Sensitivity of Model Results In Increasing Returns Cases}

\begin{tabular}{|c|c|c|}
\hline \multicolumn{2}{|c|}{$\begin{array}{l}\text { Welfare gains in Hicksian EV in \$bill } 1992 \text { from extending the } \\
\text { sales tax to cover food for household use on an equal yield basis }\end{array}$} & \\
\hline A. & Central Case & 0.82 \\
\hline B. & $\begin{array}{l}\text { Halving the elasticity of substitution in preferences between } \\
\text { home meals and restaurant meals }\end{array}$ & 0.21 \\
\hline $\mathrm{C}$. & $\begin{array}{l}\text { Halving the elasticity of substitution between food and time } \\
\text { in household production }\end{array}$ & 0.83 \\
\hline D. & Combining $\mathrm{A}$ and $\mathrm{B}$ & 0.31 \\
\hline E. & $\begin{array}{l}\text { Increasing proportion of variable costs by } 50 \% \text { total costs } \\
\text { in market production }\end{array}$ & 0.37 \\
\hline F. & Halving the number of firms assumed in the base case & 0.82 \\
\hline
\end{tabular}




\section{CONCLUSION}

In this paper we have explored the implications of scale economies in household and market production for the exemption of food from the tax base under a VAT or a retail sales tax. Such exemptions are usually justified on distributional grounds, here we analyze the efficiency implications of such exclusions. Since food is a non taxed input into household production, we argue that there seems to be a presumption for taxing food used in this way, and more than fully taxing it given the non taxation of labour inputs into household production.

We first build a simple constant returns to scale simulation model in which the outcome depends on the elasticities used. In a central case, the desirability of taxing food clearly emerges and the size of gains also increases rapidly in the income tax rate if an existing income tax is incorporated in both base and counterfactual cases. We then turn to the case of increasing returns to scale at both market (restaurant) and household level; arguing that scale economies at household level imply a different organizational form from the market. The number of producers in each household is fixed; and households marginal rather than average cost price. We use a Dixit-Stiglitz-Chamberlinian formulation of market activity capturing variety across restaurants. Firms face fixed and variable costs, there is free entry, and mark-ups in equilibrium cover fixed costs. Compared to the constant returns case, taxing food in home use moves resources into market activity where increased variety yields considerably larger welfare gains. These can be further increased by subsidizing restaurant meals.

We conclude by arguing that an efficiency case not only for taxing food, but for more than fully taxing food, emerges as strongly supported from these calculations. If the food exemption as 
distributional policy is poorly targeted and of limited effectiveness, as efficiency based policy it seems counterproductive. 


\section{BIBLIOGRAPHY}

Atkinson A.B. \& J.E. Stiglitz (1980) "Lectures on Public Economics", Maidenhead: McGraw Hill.

Bloskie C. (1995) "An Overview of Recent Trends in Personal Expenditure", Canadian Economic Observer, Statistics Canada, Ottawa.

Boskin M.J. (1975) "Efficiency Aspects of the Differential Tax Treatment of Market and Household Economic Activity", Journal of Public Economics 4, pp.1-25.

Cremer H. and J.F. Thisse (1994) "Commodity Taxation in a Differential Oligopoly", International Economic Review, 35, pp.613-633.

Davies J. B.(1986) "Manufacturers' Sales Tax, Value-Added Tax and Effective Tax Incidence", in Report of Proceedings of the Thirty-Seventh Tax Conference, 1985 Conference Report, 5:114. Toronto: Canadian Tax Foundation.

Delipalla S. and M. Keen (1992) "The Comparison Between Ad Valorem and a Specific Taxation Under Imperfect Competition", Journal of Public Economics, 49, pp.351-367.

Dierickx I., C. Matutes and D. Niven (1988) "Indirect Taxation and Cournot Equilibrium", International Journal of Industrial Organization, 6, pp.385-399.

Dixit A.K. \& J.E. Stiglitz (1977) "Monopolistic Competition and Optimum Product Diversity", American Economic Review, 67, pp. 297-308.

Frederick J.A. (1995) As Time Goes By......Time Use of Canadians, Statistics Canada; Ottawa.

Katz M.L. and H.S. Rosen (1985) "Tax Analysis - An Oligopoly Model”, Public Finance Quarterly, 13, pp.3-20.

Konishi H. (1990) "Final and Intermediate Goods Taxation in an Oligopolistic Economy with Free Entry", Journal of Public Economics, 42, pp.371-386.

Konishi H., M. Okuno-Fujiwara and K. Suzumura (1990) "Oligopolistic Competition and Economic Welfare: A General Equilibrium Analysis of Entry Regulation and Tax-Subsidy Schemes", Journal of Public Economics, 42, pp.67-88.

Myles G.D. (1989) "Ramsey Tax Rules for Economies with Imperfect Competition", Journal of Public Economics, 38, pp.95-115.

Myles G.D. (1995a) "Imperfect Competition and Industry-Specific Input Taxes", Public Finance Quarterly, 23, pp.336-355. 
Myles G.D. (1995b) Public Economics, Cambridge: Cambridge University Press.

Newberry D.N. (1986) “On the Desirability of Input Taxes”, Economics Letters, 20, pp.267-270.

Piggott J. \& J. Whalley (1998) "VAT Base Broadening, Self Supply, and The Informal Economy", NBER Working Paper 6349.

Sandmo A (1990) “Tax Distortions and Household Production”, Oxford Economic Papers 42, pp. 78-90.

Statistics Canada (1995) National Income and Expenditure Accounts, Market Research Handbook, Statistics Canada, Ottawa.

Statistics Canada (1996) National Income and Expenditure Accounts, Annual Estimates 1984-1995, Statistics Canada, Ottawa.

Statistics Canada (1996) The Input-Output Structure of the Canadian Economy, 1992. Statistics Canada, Ottawa.

Stern N. (1987) "The Effects of Taxation, Price Control and Government Contracts in Oligopoly and Monopolistic Competition”, Journal of Public Economics, 32, pp.133-158.

Wilson J.D. (1989) "On the Optimal Tax Base for Commodity Taxation", American Economic Review 79, pp. 1196-1206. 